DE

M E D I C I N A

T R O P I C A L

$\mathrm{DE}$

S ÃO PAULO

JOURNAL OF THE SÃO PAULO INSTITUTE OF TROPICAL MEDICINE

${ }^{1}$ Universidade Federal do Paraná, Programa de Pós-Graduação em Assistência

Farmacêutica, Curitiba, Paraná, Brazil

Universidade Federal do Paraná, Programa de Pós-Graduação em Ciências Farmacêuticas, Curitiba, Paraná, Brazil

Correspondence to: Roberto Pontarolo Universidade Federal do Paraná, Departamento de Farmácia, Av. Pref. Lothario Meissner, 632, Jardim Botânico, CEP 80210170, Curitiba, PR, Brazil Tel: + 554133604094

E-mail: pontarolo@ufpr.br

Received: 14 August 2018

Accepted: 17 October 2018

\section{Quality of life of Brazilian chronic hepatitis C patients treated with interferon-free therapies}

\author{
Fabiane Mateus Siqueira', Vinicius Lins Ferreira², Helena Hiemisch Lobo \\ Borba $^{2}$, Roberto Pontarolo ${ }^{1,2}$
}

\section{ABSTRACT}

Due to the severity of chronic hepatitis $\mathrm{C}$, there are multiple factors that can negatively affect the quality of life of infected patients. The aim of this study was to evaluate changes in the health-related quality of life $(\mathrm{HRQoL})$ in patients under second-generation direct-acting antiviral (DAA) (interferon-free) therapies and to assess treatment effectiveness. This was an observational study conducted in Curitiba (Brazil) using two instruments (a generic and a specific) for measuring the quality of life in patients with chronic hepatitis $\mathrm{C}$, the Short Form-36 (SF-36) and the Chronic Liver Disease Questionnaire (CLDQ) for liver disease evaluation. The study included patients receiving any interferon-free therapy for hepatitis C treatment during 2016 and 2017. Data were collected before, during, and after treatment regarding the two questionnaires, effectiveness and safety. Fifty-six patients fulfilled all eligibility criteria and were included for analysis. Sustained virological response was obtained in $88 \%$ of the patients. They were mainly genotype 1 , cirrhotic and treated with sofosbuvir combined with daclatasvir or sofosbuvir with simeprevir. Improvement in the quality of life was observed for several domains in both questionnaires $(\mathrm{p}<0.05)$ in the comparison before and after treatment. Patients receiving sofosbuvir with daclatasvir had significantly lower scores compared to the group receiving sofosbuvir with simeprevir. Second-generation DAA therapies were effective and have considerably increased the HRQoL of patients with chronic hepatitis $\mathrm{C}$ virus.

KEYWORDS: Health-related quality of life. Hepatitis C. Interferon-free. SF-36. Chronic Liver Disease Questionnaire. CLDQ.

\section{INTRODUCTION}

Patients' emotional, social and physical well-being have been increasingly investigated and recognized as an important outcome, particularly in developed countries presenting a high prevalence of chronic diseases. The measurement of these subjective parameters is translated by the health-related quality of life (HRQoL), which quantifies the impact of a disease and its treatment on the individual ${ }^{1,2}$.

Standing out among widely investigated chronic diseases is hepatitis $\mathrm{C}$, an infectious condition that affects 71 million people worldwide ${ }^{3}$. In Brazil, a lowincome country, it is estimated that the chronic infection by hepatitis $\mathrm{C}$ virus $(\mathrm{HCV})$ affects more than 2 million people 4 .

Considering the severity of chronic hepatitis $\mathrm{C}$, recognized as a major public health issue, its proper management is paramount for controlling infection dissemination, especially due to its slow progression and high number of chronic cases, making early diagnosis difficult. This fact postpones the beginning of 
treatment, which is decisive for stopping the progression of the disease. Hence, several treatment options have emerged in recent years, highlighting direct-acting antivirals (DAAs) $)^{5}$. Since the approval of the first-generation DAAs by the Food and Drug Administration (FDA) in 2011, treatment regimens have undergone numerous changes. The latest therapies (since 2014) include interferon-free schemes, more effective in terms of sustained virological response (SVR) and associated with less adverse events when compared to previous regimens ${ }^{6,7}$. The new wave of therapies with interferon-free schemes was incorporated into the Brazilian guidelines for chronic hepatitis $\mathrm{C}$ treatment in $2015^{4}$.

In terms of quality of life, since chronic hepatitis $\mathrm{C}$ may promote extra-hepatic manifestations (e.g. depression, cognitive deficit, and arthralgia) even in the absence of hepatic impairment, HRQoL has a negative impact on both, physical and mental aspects. As a consequence, patients may present productivity and work capacity loss, in addition to difficulties in the execution of other daily activities. This scenario imposes a significant socio-economic burden on patients and their relatives, as well as on the health system. Therefore, the assessment of patients' quality of life is highly relevant ${ }^{8-11}$. In this sense, several instruments are available to measure HRQoL in this population. The most commonly used questionnaires are the Medical Outcomes Study 36-item Short-Form Health Survey (SF-36) and the EuroQoL-EQ-5D, which are both generic, and the Chronic Liver Disease Questionnaire (CLDQ), which is specific for liver diseases ${ }^{12-14}$.

Since chronic hepatitis $\mathrm{C}$ treatment guidelines have been recently updated in Brazil ${ }^{15}$ and considering the lack of data regarding the quality of life of patients treated in public health institutions in the country, this study aimed to evaluate changes in the HRQoL in patients under interferonfree therapies and to assess treatment effectiveness.

\section{MATERIAL AND METHODS}

\section{Study design and participants}

This is a prospective observational study carried out in the Pharmacy of Specialized Component of Pharmaceutical Assistance in the city of Curitiba, South Brazil. It was conducted between 2016 and 2017. All patients diagnosed with HCV infection who were over 18 years of age and eligible for treatment with interferon-free regimens were invited to participate in the study, including those co-infected with hepatitis B virus (HBV) and with human immunodeficiency virus (HIV). Inclusion criteria also followed the recommendations of the 2015 Brazilian guidelines ${ }^{4}$. Patients with incapacitating extra-hepatic neurological manifestations, with any condition that prevented the understanding and completion of the questionnaires, who were lost to follow-up after the end of treatment, who did not complete the questionnaires (more than three unanswered questions), or who had the questionnaires answered by third parties were excluded from the study.

\section{Treatment regimens}

We evaluated the treatment regimens with DAAs approved by the Brazilian Ministry of Health and provided by the public health system according to the 2015 Brazilian guidelines for chronic hepatitis $\mathrm{C}$ treatment. Therapeutic regimens included sofosbuvir (SOF) $400 \mathrm{mg}$ PO q/day, daclatasvir (DAC) $60 \mathrm{mg}$ PO q/day, simeprevir (SMV) $150 \mathrm{mg}$ PO q/day, and ribavirin (RBV) $250 \mathrm{mg}$ (11 mg/kg/day PO or $1 \mathrm{~g} \mathrm{PO}[<75 \mathrm{~kg}]$ or $1.2 \mathrm{~g}$ PO [> $75 \mathrm{~kg}])$.

\section{Data collection}

After identifying eligible patients and obtaining the signed informed consent, we collected baseline and disease history data of the participants. Baseline data included age, time of diagnosis, history of alcoholism and/or injecting drugs, other comorbidities, ethnicity, marital status, sex, and schooling. The history related to the disease comprised previous treatments and respective responses, assessment of hepatic impairment, stage of liver fibrosis and/or presence of cirrhosis, presence of extra-hepatic manifestations, virus genotype, quantitative viral load (HCV-RNA), and HIV coinfection.

For a comprehensive assessment of patients' HRQoL, the SF-36 and CLDQ were applied before starting and after the end of treatment. The SF-36 is the most widely used generic instrument. It is a multidimensional questionnaire consisting of 36 items and is divided into eight domains: physical functioning (PF), role limitation due to physical health $(\mathrm{PH})$, pain $(\mathrm{P})$, general health $(\mathrm{GH})$, vitality $(\mathrm{V})$, social functioning (SF), emotional well-being (EW) and mental health $(\mathrm{MH})$. Results are expressed as a score ranging from 0 to 100 for each of the eight scales, with higher scores indicating a better quality of life $\mathrm{e}^{16,17}$.

The CLDQ, a specific instrument, is composed of 29 questions distributed in six domains, including abdominal symptoms (AS), fatigue (FA), systemic symptoms (SS), activity (AT), emotional function (EF), and worry (WO). Scores range from 1 (worst) to 7 (least severe), in which higher scores indicate a minimum frequency of symptoms and, consequently, a better quality of life. An overall score is calculated by averaging the six dimensions $\mathbf{s}^{14,18,19}$. 
In addition, information on adverse events and treatment discontinuation were collected. Data on treatment effectiveness were assessed by SVR rates 12 or 24 weeks after treatment completion. Patients were followed up until six months after the end of treatment. All data collected were documented in a clinical record designed specifically for the study and then compiled in an Excel spreadsheet using the software Microsoft Office Excel $^{\circledR} 2013$.

\section{Ethical aspects}

The present study was conducted according to the Declaration of Helsinki and the Resolution 466/2012 of the Brazilian National Health Council. The Ethics Committee on Human Research of the Universidade Federal do Parana and the Ethics Committee of the State Secretary of Health (Curitiba, Parana, Brazil) approved the study protocol $\left(\mathrm{N}^{\circ}\right.$ 68049517.9.3001.5225). We received authorization to conduct the study in the pharmacy of the Second Regional Health by the direct coordination and by the Department of Pharmaceutical Assistance of the Parana State. All participants provided written informed consents.

\section{Statistical analysis}

Data recorded in Microsoft Office Excel ${ }^{\circledR} 2013$ were processed according to each applied instrument and then transferred to the software IBM $^{\circledR}$ SPSS $^{\circledR}$ Statistics version 20 (Armonk, NY: IBM Corp.), in which all statistical analyses were performed. Qualitative variables were expressed as absolute and relative frequencies, and quantitative variables were presented as means and standard deviations (SD).

The Kolmogorov-Smirnov test was used to verify the distribution of parameters. As data distribution was not normal, non-parametric tests were applied in the comparative analysis. For statistical analysis of the HRQoL instruments, we applied the non-parametric test for Wilcoxon-related samples, in which domains were evaluated in pairs, with values referring to before and after treatment, for each instrument. This test allowed the comparison of HRQoL within a single group of patients. The analysis to compare quality of life in patients receiving different treatments was performed using the Mann-Whitney U test. For all analyses, the significance level of $\mathrm{p}<0.05$ was adopted, with a confidence level of $95 \%$.

\section{RESULTS}

\section{Baseline characteristics}

In the period in which the study was conducted,
324 patients started DAA treatment and were invited to participate in the research, but only 112 accepted. Finally, 56 patients fulfilled all eligibility criteria and were included for analysis. All baseline characteristics and socio-demographic data are presented in Table 1.

Table 1 - Socio-demographic and clinical variables of the study population

\begin{tabular}{|c|c|}
\hline Parameter & Total patients $(n=56)$ \\
\hline \multicolumn{2}{|l|}{ Gender, n (\%) } \\
\hline Male & $37(66 \%)$ \\
\hline Female & $19(34 \%)$ \\
\hline Mean age $(\mathrm{SD})$ years & $57.4 \pm 11.4$ \\
\hline \multicolumn{2}{|l|}{ Treatment received } \\
\hline $\mathrm{SOF}+\mathrm{DAC} \pm \mathrm{RBV}$ & $38(67.8 \%)$ \\
\hline $\mathrm{SOF}+\mathrm{SMV} \pm \mathrm{RBV}$ & $17(30.3 \%)$ \\
\hline $\mathrm{SOF}+\mathrm{RBV}$ & $1(1.7 \%)$ \\
\hline Time since diagnosis, years (SD) & $10.87 \pm 9.67$ \\
\hline \multicolumn{2}{|l|}{ Genotype } \\
\hline 1 & $42(75 \%)$ \\
\hline 2 & $1(1.7 \%)$ \\
\hline 3 & $13(23.2 \%)$ \\
\hline \multicolumn{2}{|l|}{ Treatment duration } \\
\hline $12 \mathrm{w}$ & $44(78.5 \%)$ \\
\hline $24 w$ & $12(21.5 \%)$ \\
\hline \multicolumn{2}{|l|}{ Metavir } \\
\hline $\mathrm{NI}$ & $15(26.7 \%)$ \\
\hline $\mathrm{F} 2$ & $9(16 \%)$ \\
\hline F3 & $15(26.7 \%)$ \\
\hline $\mathrm{F} 4$ & $17(30.3 \%)$ \\
\hline Patients previously treated & $35(62 \%)$ \\
\hline Viral load $\geq 800.000 \mathrm{IU} \mathrm{mL}^{-1}$ & $27(48 \%)$ \\
\hline \multicolumn{2}{|l|}{ Race } \\
\hline White & $41(73.2 \%)$ \\
\hline Black & $5(9 \%)$ \\
\hline Others & $10(17 \%)$ \\
\hline \multicolumn{2}{|l|}{ Marital status } \\
\hline Married & $31(55 \%)$ \\
\hline Single & $10(17.8 \%)$ \\
\hline Separated & $10(17.8 \%)$ \\
\hline Widowed & $5(9 \%)$ \\
\hline \multicolumn{2}{|l|}{ Educational level } \\
\hline Illiterate & $1(1.7 \%)$ \\
\hline Elementary school & $8(14.2 \%)$ \\
\hline Secondary school & $29(51 \%)$ \\
\hline High school & $18(32 \%)$ \\
\hline Patients with other comorbidities & $33(59 \%)$ \\
\hline Patients with addictions & $16(28 \%)$ \\
\hline
\end{tabular}

Abbreviations: NI: not informed; RBV: ribavirin; SOF: sofosbuvir; SMV: simeprevir 


\section{Evaluation of the quality of life}

The HRQoL of hepatitis $\mathrm{C}$ patients was improved after the use of second-generation DAAs. The evaluation of HRQoL before and after treatment through SF-36 and CLDQ showed an improvement in different domains (Table 2). In the case of SF-36, a statistical difference was observed $(\mathrm{p}<0.05)$ - i.e., an increase in patients' HRQoL - in six of the eight domains: PF, PH, P, GH, V, and MH. Patients have also presented significantly higher averages after treatment $(\mathrm{p}<0.05)$ in four of the six domains in the CLDQ: EF, WO, SS and overall score.

To compare the quality of life in patients receiving different treatments (SOF + DAC versus SOF + SMV, both with or without RBV) another analysis was performed. We observed that patients receiving SOF $+\mathrm{DAC} \pm \mathrm{RBV}$ had significantly lower scores before and after treatment compared to the ones receiving SOF + SMV (Table 3).

\section{Outcomes regarding treatment effectiveness and safety}

Data of two patients were not available for effectiveness outcomes (missing data); therefore, they were excluded from this analysis. SVR was obtained in 48 of 54 patients $(88.8 \%)$. Regarding treatment, 32 of 36 patients who received $\mathrm{SOF}+\mathrm{DAC} \pm \mathrm{RBV}$ and 16 of 17 patients who received SOF + SMV \pm RBV achieved SVR $(88.8 \%$ and
$94.1 \%$, respectively). The only patient who was treated with SOF + RBV was cured.

Only five of the 56 patients (8.9\%) who were evaluated for safety outcomes did not present any adverse events. Among the most commonly reported adverse events during treatment, the following stand out: headache (57\%), fatigue $(46 \%)$, muscle pain (32\%), sleep problems (35\%), itching (30\%), nausea (26\%), dizziness (21\%) and diarrhea (14\%). No patients discontinued treatment due to adverse events.

\section{DISCUSSION}

The present study evaluated the use of antiviral treatment and changes in the quality of life in patients infected with HCV.

A previous study conducted in Brazil compared the quality of life of chronic hepatitis $\mathrm{C}$ patients receiving antiviral interferon-based therapies, including interferon and RBV, in some cases combined with first-generation DAAs boceprevir and telaprevir ${ }^{20}$. Besides the clinical conditions of those patients, HRQoL was affected by treatment complications, which were associated with a significant number of side effects, low efficacy, treatment discontinuations and the requirement of frequent injections ${ }^{21-23}$.

In the present study, most patients received $\mathrm{SOF}+$ $\mathrm{DAC} \pm \mathrm{RBV}(67.8 \%)$, which is explained by the baseline characteristics of evaluated individuals. This treatment

Table 2 - Comparison of SF-36 and CLDQ scores between patients before and after treatment

\begin{tabular}{lcccc}
\hline Domains of SF-36 and CLDQ & & Before treatment & After treatment & p-value \\
\hline \multirow{6}{*}{ SF-36 } & PF & $56( \pm 66.4)$ & $71.7( \pm 28.7)$ & $0.043^{*}$ \\
& PH & $44.6( \pm 43.6)$ & $60.7( \pm 43.9)$ & $0.014^{\star}$ \\
& P & $52.8( \pm 25.9)$ & $62.7( \pm 25)$ & $0.006^{\star}$ \\
& GH & $54.11( \pm 24.7)$ & $62.9( \pm 24.8)$ & $0.002^{*}$ \\
& V & $50.4( \pm 26.8)$ & $60( \pm 28)$ & $0.007^{\star}$ \\
& SF & $64.2( \pm 30.7)$ & $71.2( \pm 32.1)$ & 0.076 \\
& EW & $46.4( \pm 45.6)$ & $55.3( \pm 46.3)$ & 0.096 \\
& MH & $59.9( \pm 24.5)$ & $67.1( \pm 22.1)$ & $0.006^{*}$ \\
\hline & AS & $4.04( \pm 1.78)$ & $4.14( \pm 1.74)$ & 0.803 \\
CLDQ & $3.35( \pm 1.65)$ & $3.75( \pm 1.64)$ & 0.083 \\
& FA & $4.26( \pm 1.7)$ & $4.32( \pm 1.65)$ & 0.507 \\
& AT & $3.55( \pm 1.62)$ & $4.01( \pm 1.44)$ & $0.007^{\star}$ \\
& EF & $3.58( \pm 1.65)$ & $4.85( \pm 1.31)$ & $0.001^{*}$ \\
WO & $4.05( \pm 1.33)$ & $4.42( \pm 1.14)$ & $0.033^{\star}$ \\
& SS & $3.81( \pm 1.31)$ & $4.25( \pm 1,13)$ & $0.003^{\star}$ \\
\hline
\end{tabular}

Note: ${ }^{*} \mathrm{p}<0.05$. Abbreviations: AS: abdominal symptoms; AT: activity; EW: emotional well-being; EF: emotional function; FA: fatigue; $\mathrm{GH}$ : general health; $\mathrm{MH}$ : mental health; P: pain; PF: physical functioning; PH: role limitations due to physical health; SF: social functioning; SS: systemic symptoms; V: vitality; WO: worry 
Table 3 - Comparison of SF-36 and CLDQ scores between SOF + DAC versus SOF + SMV patients before and after treatment.

\begin{tabular}{|c|c|c|c|c|c|c|c|}
\hline \multicolumn{2}{|c|}{ Domains of SF-36 and CLDQ } & \multirow{2}{*}{$\begin{array}{c}\text { Before treat- } \\
\text { ment with SOF } \\
+ \text { DAC } \pm \text { RBV }\end{array}$} & \multirow{2}{*}{$\begin{array}{l}\begin{array}{c}\text { Before treat- } \\
\text { ment with SOF } \\
+ \text { SMV } \pm \text { RBV }\end{array} \\
70.2( \pm 30.8)\end{array}$} & \multirow{2}{*}{$\frac{p \text {-value }}{0.493}$} & \multirow{2}{*}{\multicolumn{2}{|c|}{$\begin{array}{cc}\text { After treatment } & \text { After treatment } \\
\text { with SOF }+ & \text { with SOF }+ \\
\text { DAC } \pm \text { RBV } & \text { SMV } \pm \text { RBV } \\
69.3( \pm 29.0) & 75.5( \pm 28.5)\end{array}$}} & \multirow{2}{*}{$\begin{array}{l}\text { p-value } \\
0.420\end{array}$} \\
\hline SF-36 & PF & & & & & & \\
\hline & $\mathrm{PH}$ & $40.1( \pm 42.9)$ & $57.3( \pm 43.9)$ & 0.217 & $51.9( \pm 44.0)$ & $77.9( \pm 39.4)$ & $0.045^{*}$ \\
\hline & $\mathrm{P}$ & $50.5( \pm 25.1)$ & $61.2( \pm 24.4)$ & 0.228 & $57.8( \pm 24.9)$ & $72.0( \pm 22.9)$ & $0.040^{*}$ \\
\hline & $\mathrm{GH}$ & $49.4( \pm 25.8)$ & $62.2( \pm 18.4)$ & 0.083 & $59.1( \pm 26.1)$ & $69.6( \pm 19.4)$ & 0.179 \\
\hline & V & $45.7( \pm 27.7)$ & $57.9( \pm 21.0)$ & 0.123 & $54.4( \pm 27.7)$ & $70( \pm 25.1)$ & $0.043^{*}$ \\
\hline & SF & $56.2( \pm 32.0)$ & $83.8( \pm 16.3)$ & $0.003^{\star}$ & $64.8( \pm 32.2)$ & $83.8( \pm 28.9)$ & $0.014^{*}$ \\
\hline & EW & $37.7( \pm 43.9)$ & $68.6( \pm 43.2)$ & $0.026^{\star}$ & $42.1( \pm 46.2)$ & $82.3( \pm 33.5)$ & $0.006^{*}$ \\
\hline & $\mathrm{MH}$ & $52.8( \pm 25.0)$ & $73.6( \pm 14.9)$ & $0.003^{\star}$ & $62( \pm 22.3)$ & $77.1( \pm 17.8)$ & $0.016^{*}$ \\
\hline \multirow[t]{7}{*}{ CLDQ } & AS & $3.9( \pm 1.8)$ & $4.1( \pm 1.7)$ & 0.862 & $4.1( \pm 1.7)$ & $4.1( \pm 1.8)$ & 0.956 \\
\hline & FA & $3.0( \pm 1.6)$ & $3.9( \pm 1.4)$ & 0.060 & $3.5( \pm 1.6)$ & $4.2( \pm 1.5)$ & 0.141 \\
\hline & AT & $4.0( \pm 1.6)$ & $4.7( \pm 1.7)$ & $0.035^{\star}$ & $4.2( \pm 1.5)$ & $4.3( \pm 1.9)$ & 0.605 \\
\hline & $\mathrm{EF}$ & $3.1( \pm 1.6)$ & $4.3( \pm 1.2)$ & $0.017^{\star}$ & $3.7( \pm 1.4)$ & $4.5( \pm 1.2)$ & 0.051 \\
\hline & WO & $3.3( \pm 1.7)$ & $4.0( \pm 1.3)$ & 0.205 & $4.6( \pm 1.4)$ & $5.3( \pm 1.0)$ & $0.031^{*}$ \\
\hline & SS & $3.9( \pm 1.3)$ & $4.2( \pm 1.3)$ & 0.629 & $4.2( \pm 1.1)$ & $4.8( \pm 1.1)$ & $0.040^{*}$ \\
\hline & Overall score & $3.5( \pm 1.3)$ & $4.2( \pm 1.1)$ & 0.087 & $4.0( \pm 1.1)$ & $4.5( \pm 0.9)$ & 0.236 \\
\hline
\end{tabular}

Note: ${ }^{*} p<0.05$. Abbreviations: AS: abdominal symptoms; AT: activity; EW: emotional well-being; EF: emotional function; FA: fatigue; $\mathrm{GH}$ : general health; $\mathrm{MH}$ : mental health; P: pain; PF: physical functioning; PH: role limitations due to physical health; SF: social functioning; SS: systemic symptoms; V: vitality; WO: worry

regimen is indicated for patients with more advanced disease, treatment-experienced, or patients coinfected with $\mathrm{HIV}$, conditions presented by a high number of patients in this cohort.

The results of this study are clear, in the sense that even with the presence of some adverse events, HRQoL of HCV patients had increased after treatment with secondgeneration DAAs. This can be explained by the fact that many patients had been cured with interferon-free therapies, which are given orally, and they have also had lower severity of adverse events, which raises the perception of quality of life of these patients ${ }^{24-26}$. Additionally, SVR rates obtained in our study were similar to previous studies results ${ }^{27,28}$.

We observed that the patients treated with SOF + SMV had a higher HRQoL compared to those patients receiving $\mathrm{SOF}+\mathrm{DAC}$. This could be explained by the fact that the latter treatment is recommended for patients in a more advanced stage of the disease and in more complex situations, including patients with genotype 3 virus, which is known as the most difficult to treat ${ }^{27-29}$.

We did not conduct an analysis on the influence of comorbidities and patient's addictions (e.g. alcoholism and illicit drug use). However, these conditions are expected to affect the patient's perceptions regarding its quality of life. A strong association of intravenous drug use with depression as well as of alcoholism with disease progression, and
HIV coinfection with fatigue resulting in impairment of psychological, physical and social HRQL domains ${ }^{11,30,31}$. According to the latest Brazilian guideline, updated in 2018, treatment for chronic hepatitis $\mathrm{C}$ comprises regimens with the following DAAs: daclatasvir; simeprevir, sofosbuvir, ombitasvir, dasabuvir, veruprevir, ritonavir, ledipasvir, elbasvir and grazoprevir. The aforementioned treatments are now available through the public health system to all patients diagnosed with $\mathrm{HCV}$ infection, regardless of the liver fibrosis stage ${ }^{15}$.

This study was carried out in 2016 and 2017 so that we followed up patients receiving the therapies encompassed in the 2015 guideline, which was a limitation of the study. Nevertheless, as the evaluated regimens are also included in the updated version of treatment protocols, the results addressed herein are useful for guiding clinicians in the decision-making process in order to ensure the best treatment option according to the patient profile and effectiveness of treatment regimen.

\section{CONCLUSION}

Second-generation DAA therapies were effective and safe for the treatment of chronic hepatitis $C$ patients. In line with these previous results, there was a substantial increase of HRQoL in patients treated with SOF + DAC 
or SOF + SMV with or without RBV, detected by the various domains of the SF-36 and CLDQ. Further studies evaluating the quality of life of patients using the other therapies included in the latest guideline should be conducted.

\section{REFERENCES}

1. Gutteling JJ, de Man RA, Busschbach JJ, Darlington AS. Overview of research on health-related quality of life in patients with chronic liver disease. Neth J Med. 2007;65:227-34.

2. Orr JG, Homer T, Ternent L, Newton J, McNeil CJ, Hudson M, et al. Health related quality of life in people with advanced chronic liver disease. J Hepatol. 2014;61:1158-65.

3. World Health Organization. Hepatitis C. [cited 2018 Oct 17]. Available from: http://www.who.int/mediacentre/factsheets/ fs164/en

4. Brasil. Ministério da Saúde. Secretaria de Vigilância em Saúde. Departamento de DST, Aids e Hepatites Virais. Protocolo clínico e diretrizes terapêuticas para Hepatite $\mathrm{C}$ e coinfecções. Brasília: Ministério da Saúde; 2015. [cited 2018 Jul 10]. Available from: http://bvsms.saude.gov.br/bvs/publicacoes/ protocolo_clinico_diretrizes_hepatite_co_coinfeccoes.pdf

5. Feeney ER, Chung RT. Antiviral treatment of hepatitis C. BMJ. 2014;348:g3308.

6. Geddawy A, Ibrahim YF, Elbahie NM, Ibrahim MA. Direct acting anti-hepatitis $\mathrm{C}$ virus drugs: clinical pharmacology and future direction. J Transl Int Med. 2017;5:8-17.

7. Zhang X. Direct anti-HCV agents. Acta Pharm Sin B. 2016;6:2631.

8. DiBonaventura M, Wagner JS, Yuan Y, L'Italien G, Langley P, Ray Kim W. The impact of hepatitis $\mathrm{C}$ on labor force participation, absenteeism, presenteeism and non-work activities. J Med Econ. 2011;14:253-61.

9. Vietri J, Prajapati G, El Khoury AC. The burden of hepatitis C in Europe from the patients' perspective: a survey in 5 countries. BMC Gastroenterol. 2013;13:16.

10. Younossi ZM, Stepanova M, Henry L, Younossi I, Weinstein A, Nader F, et al. Association of work productivity with clinical and patient-reported factors in patients infected with hepatitis C virus. J Viral Hepat. 2016;23:623-30.

11. Yeoh SW, Holmes AC, Saling MM, Everall IP, Nicoll AJ. Depression, fatigue and neurocognitive deficits in chronic hepatitis C. Hepatol Int. 2018;12: 294-304.

12. Campolina AG, Bortoluzzo AB, Ferraz MB, Ciconelli RM. Validação da versão brasileira do questionário genérico de qualidade de vida short-form 6 dimensions (SF-6D Brasil). Cienc Saude Coletiva. 2011;16:3103-10.

13. Häuser W, Holtmann G, Grandt D. Determinants of health-related quality of life in patients with chronic liver diseases. Clin Gastroenterol Hepatol. 2004;2:157-63.
14. Younossi ZM, Guyatt G, Kiwi M, Boparai N, King D. Development of a disease specific questionnaire to measure health related quality of life in patients with chronic liver disease. Gut. 1999;45:295-300.

15. Brasil. Ministério da Saúde. Secretaria de Vigilância em Saúde. Departamento de Vigilância, Prevenção e Controle das Infecções Sexualmente Transmissíveis, do HIV/Aids e das Hepatites Virais. Protocolo clínico e diretrizes terapêuticas para hepatite C e coinfecções. Brasília : Ministério da Saúde; 2017. [cited 2018 Jul 10]. Available from: http://bvsms.saude.gov.br/ bvs/publicacoes/protocolo_clinico_diretrizes_terapeuticas_ hepatite_c_coinfeccoes.pdf

16. Laucis NC, Hays RD, Bhattacharyya T. Scoring the SF-36 in orthopaedics: a brief guide.J Bone Joint Surg Am. 2015;97:1628-34

17. Lins L, Carvalho FM. SF-36 total score as a single measure of health-related quality of life: scoping review. SAGE Open Med. 2016;4:2050312116671725.

18. Mucci S, Citero VA, Gonzalez AM, De Marco MA, NogueiraMartins LA. Adaptação cultural do Chronic Liver Disease Questionnaire (CLDQ) para população brasileira. Cad Saude Publica. 2010;26:199-205.

19. Chang SC, Yang SS, Chang CC, Lin CC, Chung YC, Li TC. Assessment of health-related quality of life in antiviral-treated Taiwanese chronic hepatitis C patients using SF-36 and CLDQ. Health Qual Life Outcomes. 2014;12:97.

20. Perlin CM, Ferreira VL, Borba HH, Wiens A, Ivantes CA, Lenzi L, et al. Quality of life in Brazilian patients with treated or untreated chronic hepatitis C. Rev Inst Med Trop Sao Paulo. 2017;59:e81.

21. Suzuki M, Ishikawa T, Sakuma A, Abe S, Abe H, Koyama F, et al. Evaluation of the health-related quality of life using the 36-item short form health survey in patients with chronic hepatitis $\mathrm{C}$ receiving pegylated interferon/ribavirin/telaprevir triple treatment. Exp Ther Med. 2016;12:3353-8.

22. Shahid I, ALMalki WH, Hafeez MH, Hassan S. Hepatitis C virus infection treatment: an era of game changer direct acting antivirals and novel treatment strategies. Crit Rev Microbiol. 2016;42:535-47.

23. Cammà C, Petta S, Enea M, Bruno R, Bronte F, Capursi V, et al. Cost-effectiveness of boceprevir or telaprevir for untreated patients with genotype 1 chronic hepatitis C. Hepatology. 2012;56:850-60.

24. World Health Organization. Guidelines for the screening, care and treatment of persons with chronic hepatitis $\mathrm{C}$ infection: updated version, April 2016, guidelines. Geneva: WHO; 2016.

25. AASLD/IDSA HCV Guidance Panel. Hepatitis C guidance: AASLDIDSA recommendations for testing, managing, and treating adults infected with hepatitis $\mathrm{C}$ virus. Hepatology. 2015;62:932-54. 
26. European Association for Study of Liver. EASL recommendations on treatment of hepatitis C 2015. J Hepatol. 2015;63:199-236.

27. Ferreira VL, Leonart LP, Tonin FS, Borba HH, Pontarolo R. Sustained virological response in special populations with chronic hepatitis $\mathrm{C}$ using interferon-free treatments: a systematic review and meta-analysis of observational cohort studies. Clin Drug Investig. 2018;38:389-400.

28. Ferreira VL, Tonin FS, Assis Jarek NA, Ramires Y, Pontarolo R. Efficacy of interferon-free therapies for chronic hepatitis C: a systematic review of all randomized clinical trials. Clin Drug Investig. 2017;37:635-46.
29. Ferreira VL, Borba HH, Wiens A, Pedroso ML, Radunz VF, Ivantes CAP, et al. Effectiveness and tolerability of directacting antivirals for chronic hepatitis $\mathrm{C}$ patients in a Southern state of Brazil. Braz J Infect Dis. 2018;22:186-92

30. Marcellin F, Préau M, Ravaux I, Dellamonica P, Spire B, Carrieri MP. Self-reported fatigue and depressive symptoms as main indicators of the quality of life (QOL) of patients living with HIV and Hepatitis C: implications for clinical management and future research. HIV Clin Trials. 2007;8:320-7.

31. Novo-Veleiro I, Alvela-Suárez L, Chamorro AJ, GonzálezSarmiento R, Laso FJ, Marcos M. Alcoholic liver disease and hepatitis $\mathrm{C}$ virus infection. World J Gastroenterol. 2016;22:1411-20. 